\title{
Habitat Utilization and Diet of the Harvest Mouse, Micromys minutus, in an Urban Environment
}

\author{
C. R. DICKMAN ${ }^{1}$
}

\begin{abstract}
Dickman C. R., 1986: Habitat utilization and diet of the harvest mouse, Micromys minutus, in an urban environment. Acta theriol., 31, 19: 249-256 [With 2 Tables].

The distribution of the harvest mouse, Micromys minutus, was surveyed in 50 discrete patches of habitat within the City of Oxford using hair sampling tubes and live trapping, and by searching for breeding nests. Mice occurred in ten habitat patches ranging in area from 0.30 ha to 1.76 ha. Animals were associated most strongly with patches containing a dense and relatively undisturbed cover of grass and herbs (orchard, scrub and long grass), but in single instances animals were found in woodland, a churchyard and an overgrown garden. Analysis of faecal pellets collected from nests and live-trapped animals showed $M$. minutus to be omnivorous. Seeds, fruit, monocotyledon and dicotyledon leaves and insects were major dietary items, but fungus, moss, root material and other invertebrates were also consumed. The harvest mouse successfully persists in the urban environment of Oxford, but has been overlooked in previous studies.

[Animal Behaviour Research Group, Department of Zoology, University of Oxford, Oxford OXI 3PS, U.K.]
\end{abstract}

\section{INTRODUCTION}

The harvest mouse, Micromys minutus (Pallas, 1771) occurs in a wide variety of habitats, but favours areas of tall, dense vegetation. In Britain, this species has been recorded most frequently in hedgerow, bramble and on the edges of fields, but it occurs also in heathland, moorland and in the tidal areas of salt marshes (Harris, 1979). Large populations of $M$. minutus may build up locally in agricultural areas. For example, Rowe \& Taylor (1964) recorded up to 110 animals in corn ricks in England; in corn ricks in Russia between 2,000 and 5,000 animals have been estimated (Sleptsov, 1947).

In correspondence with its ability to exploit diverse habitats, $\boldsymbol{M}$. $\mathbf{m i}$ nutus probably eats a wide variety of foods. Captive animals eat seeds, green shoots, fruit and meat, and may chase and consume moths and flies (Trout, 1977, 1978a). Information on the diet of wild M. minutus is sparse. However, in Russian populations cereal and grass seeds pre-

1 Present address: Department of Zoology, University of Western Australia, Nedlands WA 6009, Australia. 
dominate in the diet in autumn and winter, while the proportion of insect and green plant material increases in spring (Sleptsov, 1947).

Despite its flexible habitat selection and diet, $M$. minutus appears to be scarce in the urban environment. Jüdes (1981) reported that this species was less abundant on dry soils near a village in Germany than in adjacent rural areas. In England, isolated records of $M$. minutus exist from Lincoln (Johnson, 1977), Sheffield (Clinging, 1984), Milton Keynes (Dickinson, 1975) and from the outskirts of London (Cotton, 1981). The effects of urbanization on $M$. minutus are poorly known. This paper aims to 1) describe the distribution of $M$. minutus in habitat patches in the City of Oxford, and 2) provide a preliminary assessment of the diet of these urban populations.

\section{MATERIAL AND METHODS}

\subsection{Study Area}

Harvest mice were recorded during a general survey of mammals carried out mostly within the limits of the City of Oxford (population 120,000). Fieldwork was conducted in 50 patches of semi-natural and disturbed vegetation. The patches range in size from 0.16 ha to 20 ha, and are surrounded by roads, walls, watercourses or cleared areas which probably restrict the movements of M. minutus. The patches together occupy $75.3 \mathrm{ha}$, and represent $1.56 \%$ of the total city area. Patch vegetation was classified as woodland, scrub, orchard, long grass, parkland, churchyard, allotment and house garden.

\subsection{Survey Methods}

Systematic searches for the breeding nests of $M$. minutus were made in each habitat patch in late autumn and early winter in 1983. Most nests were detected in brambles, grass or reeds, $15 \mathrm{~cm}$ to $65 \mathrm{~cm}$ above the ground, but one was found among willow herbs, Epilobium angustifolium (L.), at a height of $1 \mathrm{~m}$. Thirty to 80 hair sampling tubes (Suckling, 1978) were set opportunistically or on grids in all habitat patches between April and October 1983, and March and June 1984, and the hairs of $M$. minutus identified by scale casting and cross-sectioning techniques (Brunner \& Coman, 1974). Thirty to 50 Longworth live traps were also set on grids in 29 habitat patches between June and August, 1983. Traps were prebaited for $24 \mathrm{~h}-36 \mathrm{~h}$ with oats and fly pupae before being set, and then checked near dawn and dusk for three consecutive days. Captured $M$. $m i$ nutus and other small mammals were uniquely toe-clipped, sexed, weighed and released.

\subsection{Analysis of Diet}

The diet of $M$. minutus was assessed by means of faecal analysis. Faecal pellets were collected from used traps or from within the breeding nests, and air dried for several days. Slides were then prepared using the method of Phillipson, 
Sarrazin-Comans and Stomatopoulos (1983), and the volume of different dietary components estimated according to the procedure of Sparks and Malechek (1968). Faecal pellets collected from the breeding nests were probably produced by several individuals. However, since these could not be distinguished, I treated the mixture of pellets from each nest as individual samples.

Several authors have questioned the reliability of faecal analysis for assessing diet, due to the problem of differential digestibility of different food items (Hansson, 1970, 1971; Ferns, 1976: Phillipson et al., 1983). To avoid undue bias, I therefore classify foods into broad dietary categories and make no attempt to identify food items to species.

\section{RESULTS}

\subsection{Distribution of M. minutus in Habitat Patches}

Micromys minutus was found in 10 of the 50 habitat patches surveyed. Mice were associated most strongly with scrubby habitats with a dense and relatively undisturbed cover of grass and herbs (Table 1). Single records of $M$. minutus were obtained from a large, overgrown garden

Table 1

Distribution of Micromys minutus in habitat patches in the City of Oxford

\begin{tabular}{lccc}
\hline Habitat & $\begin{array}{c}\text { Total No. } \\
\text { of patches }\end{array}$ & $\begin{array}{c}\text { No. patches with } \\
\text { M. minutus }\end{array}$ & $\begin{array}{c}\% \\
\text { occurrence }\end{array}$ \\
\hline Woodland & 12 & 1 & 8.3 \\
Scrub & 9 & 3 & 33.3 \\
Orchard & 2 & 2 & 100.0 \\
Long grass & 4 & 2 & 50.0 \\
Parkland & 5 & 0 & 0.0 \\
Churchyard & 3 & 1 & 33.3 \\
Allotment & 5 & 0 & 0.0 \\
House garden & 10 & 1 & 10.0 \\
\hline
\end{tabular}

and a patch of woodland with a grassy understory; none was obtained from cultivated parkland or allotment. The ten patches ranged in area from 0.30 ha to 1.76 ha.

A total of 26 nests was found in nine patches, with $1-7$ nests occurring in any one patch. The current presence of $M$. minutus was detected by hair sampling tubes in five of these patches and also in the tenth patch where no nests were found. Longworth traps captured only four individuals in two patches of scrub, despite a total trapping effort of 3858 trap nights.

Most breeding nests were constructed of grass species which were available locally within each patch. Nine nests were constructed using 
Dactylis glomerata L., six using Agropyron spp., five using Phleum pratense L., two using Arrhenatherum elatius (L.), one each using Avenula pubescens (Huds.) and Phragmites australis; the nest material used for the remaining two nests could not be identified.

\subsection{Analysis of Diet}

Faecal pellets were obtained from 18 breeding nests in orchard, long grass and scrub between September and January, and the dietary components are shown in Table 2. Micromys minutus is clearly omnivorous in each habitat. Seeds, fruit, green leaves and insects were consistently

\section{Table 2}

Percentage volume of foods found in the diet of Micromys minutus in three different habitats in the City of Oxford. Values are means Istandard deviation; $H$ is the Kruskal-Wallis statistic.

\begin{tabular}{|c|c|c|c|c|c|}
\hline No. of nests & $\underset{9}{\text { Orchard }}$ & ${ }_{4}^{\text {Long grass }}$ & $\underset{5}{\text { Scrub }}$ & $H$ & $P$ \\
\hline Fungus & $9.7 \pm 9.2$ & $3.3 \pm 4.7$ & $2.6 \pm 2.8$ & 3.28 & n.s. \\
\hline $\begin{array}{l}\text { Moss } \\
\text { Monocotyledon }\end{array}$ & $0.2 \pm 0.7$ & 0 & $3.8 \pm 3.6$ & 3.39 & n.s. \\
\hline $\begin{array}{l}\text { Leaf } \\
\text { Dicotyledon }\end{array}$ & $12.4 \pm 8.4$ & $20.8 \pm 14.5$ & $6.8 \pm 6.9$ & 4.51 & n.s. \\
\hline Leaf & $9.4 \pm 7.6$ & $3.8 \pm 4.8$ & $19.0 \pm 11.8$ & 4.81 & n. \\
\hline Fruit & $27.2 \pm 20.3$ & $6.3 \pm 4.8$ & $14.8 \pm 6.4$ & 6.62 & $<0.05$ \\
\hline Seed & $20.2 \pm 13.3$ & $45.0 \pm 19.6$ & $30.0 \pm 12.8$ & 4.20 & n.s. \\
\hline Root & $0.2 \pm 0.7$ & $1.0 \pm 2.0$ & $4.2 \pm 5.9$ & 1.13 & n.s. \\
\hline $\begin{array}{l}\text { Insect } \\
\text { Other }\end{array}$ & $12.0 \pm 11.4$ & $15.5 . \pm 10.0$ & $16.2 \pm 12.2$ & 1.22 & n.s. \\
\hline invertebrate & $3.8 \pm 4.8$ & $0.3 \pm 0.5$ & 0 & 5.08 & \\
\hline Vertebrate & $0.3 \pm 1.0$ & 0 & $0.2 \pm 0.5$ & 0.23 & n.s. \\
\hline Other ${ }^{1}$ & $4.4 \pm 5.3$ & $4.3 \pm 4.4$ & $2.4 \pm 2.9$ & 0.38 & n.s. \\
\hline
\end{tabular}

1 Inciudes fibrous material, plant hooks and hairs which could not be classified with other dietary categories.

well represented, whereas other invertebrates (mainly spiders and snails), fungus, moss, vertebrate and root material appeared less frequently. Consumption of fruit (apple and blackberry) was higher in orchard than in long grass or scrub; no other statistically significant difference between the habitats was detected. Most invertebrate remains were adult and larval beetles (families Scarabaeidae, Chrysomelidae and Coccinellidae), lepidopteran larvae (family Noctuidae?) and small homopteran bugs. Vertebrate remains were found in two nests only and comprised hairs of $M$. minutus and the vole Microtus agrestis (L.). Faecal pellets from the four live-trapped $M$. minutus contained similar categories of food to pellets collected from the nests. Mean values are: 
of monocotyledon and dicotyledon leaves is highest in long grass and scrub, and again reflects the local abundance of these food categories. In Warszawa, the striped field mouse, Apodemus agrarius (Pallas), has exploited the urban environment more effectively than other species of small rodents (Andrzejewski et al., 1978). This species also eats a wide variety of plant and animal prey, but the diet is less diverse in urban than in suburban parts of the city (Babinska-Werka, 1981). In the present study there was little indication of dietary restriction in urban $M$. minutus; however, comparative dietary information from non-urban areas in Britain has not been obtained.

Colonization of the study areas by $M$. minutus has possibly been facilitated in recent times by the system of rivers, rail and canal links which connect Oxford City to more rural surroundings. Potential source populations of $M$. minutus are known from Wytham Woods and areas of pasture on the edge of the city area (Oxford County Museum Records), and the city is now ringed by an extensive green belt (Scargill, 1980). Yet, the extent of use of such dispersal routes is unclear. Trout (1978b) estimated that the mean trap-revealed lifetime movement of animals was only $32.4 \mathrm{~m}$, and recorded no movements greater than $100 \mathrm{~m}$. It is clearly possible that some populations of $M$. minutus have persisted in suitable patches of habitat in Oxford throughout the period of city growth. Archaeological records show that species of small rodents have been present in other British cities for several centuries (Armitage, 1985). The continuous presence of $M$. minutus in urban centres may thus have been simply overlooked, as have populations of this species in many other parts of its range (Harris, 1979).

Acknowledgements: I thank British Rail for a permit to survey harvest mice and other small mammals on railway property, and the City Council, college wardens, park keepers, clergy and many residents of Oxford for permission to work on their land. I also thank staff at the Herbarium of the Oxford Botanical Garden for helping to identify species of grass, C. P. Doncaster and J. Winter for assistance with fieldwork, and V. T. Read for commenting on the manuscript. Funding was provided in part by grants from the British Ecological Society and Mammal Society.

\section{REFERENCES}

1. Andrzejewski R., Babińska-Werka J., Gliwicz J. \& Goszczyński J., 1978: Synurbanization processes in population of Apodemus agrarius. I. Characteristics of population in an urbanization gradient. Acta theriol., 23: $341-358$.

2. Armitage P. L., 1985: Small mammal faunas in later Mediaeval towns. Biologist, 32: $65-71$.

3. Babińska-Werka J., 1981: Food of the striped field mouse in different types of urban green areas. Acta theriol., 26: 285-299. 
4. Brunner H. \& Coman B. J., 1974: The identification of mammalian hair. Inkata Press, Melbourne.

5. Clinging V., 1984: Sheffield mammal report 1980-1983. Sorby Rec., 22: 3-10.

6. Cotton J., 1981: Mammal recording in the London area. London Nat., 60: 94-95.

7. Dickinson N. M., 1975: Ecological studies in Milton Keynes XII. Small mammals. Milton Keynes Development Corporation, Milton Keynes.

8. Dickman C. R., 1986: A method for censusing small mammals in urban habitats. J. Zool., Lond. (in press).

9. Dickman C. R. \& Doncaster C. P., 1986: The ecology of small mammals in urban habitats. I. Populations in a patchy environment. J. Anim. Ecol. (submitted).

10. Dillon P. \& Browne M., 1975: Habitat selection and nest ecology of the harvest mouse Micromys minutus (Pallas). Wilts. Nat. Hist. Mag., 70: 3-9.

11. Elton C., 1939: Mammals: [In: Salzman L. F. Ed., "The Victoria history of the County of Oxford, 1"]. Oxford University Press, London.

12. Ferns P. N., 1976: Diet of a Microtus agrestis population in south west Britain. Oikos, 27: 506-511.

13. Hansson L., 1970: Methods of morphological diet micro-analysis in rodents. Oikos, 21: 255-266.

14. Hansson L ., 1971: Habitat, food and population dynamics of the field vole Microtus agrestis (L.) in south Sweden. Viltrevy, 8: 267-378.

14. Harris S., 1979: History, distribution, status and habitat requirements of the harvest mouse (Micromys minutus) in Britain. Mammal Rev., 9: 159-171.

16. Johnson M., 1977: The harvest mouse (Micromys minutus); current distribution and nesting habits in Lincolnshire. Trans. Lincs. Nats. Union, 19: 75-77.

17. Jüdes U., 1981: Some notes on population density of Micromys minutus in. a secondary biotope. Z. Säugetierk., 46: 266-268.

18. Phillipson J., Sarrazin-Comans M. \& Stomatopoulos C., 1983: Food consumption by Microtus agrestis and the unsuitability of faecal analysis for the determination of food preference. Acta theriol., 28: 397-416.

19. Rowe F. P. \& Taylor E. J., 1964: The numbers of harvest-mice (Micromys minutus) in corn-ricks. Proc. Zool. Soc. Lond., 142: 181-185.

20. Scargill D. I., 1980: Conservation and the Oxford green belt. [In: Rowley T. Ed., "The Oxford region"]. Oxford University Department for External Studies, Oxford.

21. Sleptsov M. M., 1947: The biology of Micromys minutus ussuricus B.-Ham. [In: "Fauna i ekologiya gryzunov 2. Materialy $k$ poznaniyu fauny $i$ flory SSSR, 8"]. Moscow.

22. Sparks D. R. \& Malechek J. C., 1968: Estimating percentage dry weight in diets using a microscopic technique. J. Range Manage., 21: 264-265.

23. Suckling G. C., 1978: A hair sampling tube for the detection of small mammals. in trees. Aust. Wildl. Res., 5: 249-252.

24. Surch R. \& Campbell J. M., 1982: An atlas of Oxfordshire mammals. Oxfordshire County Council Occ. Pap. No. 1, Oxford.

25. Trout R., 1977: Genus Micromys [In: Corbet G. B. \& Southern H. N. Eds, "The handbook of British mammals"]. Blackwell, Oxford.

26. Trout R. C., 1978a: A review of studies on captive harvest mice (Micromys: minutus (Pallas)). Mammal Rev., 8: 159-175.

27. Trout R. C., 1978b: A review of studies on populations of wild harvest mice (Micromys minutus (Pallas)). Mammal Rev., 8: 143-158. 
fungus $1.5 \pm 1.9 \%$, monocotyledon leaf $23.0 \pm 9.5 \%$, dicotyledon leaf $15.0 \pm$ $\pm 4.1 \%$, fruit $23.8 \pm 4.8 \%$, seed $26.2 \pm 8.5 \%$, root $1.8 \pm 2.1 \%$, insect $7.8 \pm$ $\pm 6.1 \%$, and other invertebrates $1.0 \pm 2.0 \%$.

\section{DISCUSSION}

In $1939 M$. minutus was thought to be absent in Oxfordshire (Elton, 1939), but by 1982 it was known from 15 different localities within the county and was reported to be "probably increasing" (Surch \& Campbell, 1982). These conflicting assessments suggest that $M$. minutus has been under-recorded in Oxfordshire in recent years, as it has been in other parts of Britain (Harris, 1979). Searching for breeding nests is probably the most reliable method of detecting the presence of $M$. minutus, but placement of hair sampling tubes, especially above ground in shrubs and dense herbage, can provide important additional information (Dickman, 1986). Longworth live traps are probably not suitable for detecting $M$. minutus at least during the summer months, unless they are set on stakes at nest height in suitable cover (Warner \& Batt, 1976). The present study, using the three survey methods, confirms that $M$. minutus is widely distributed in the City of Oxford in patches of habitat providing a relatively continuous and undisturbed cover of grasses and herbs.

The habitat preference of $M$. minutus in Oxford is similar to that exhibited by animals in more rural areas (e.g. Dillon \& Browne, 1975; Trout, 1977; Harris, 1979). This suggests that $M$. minutus may persist in the urban environment provided that refuge areas of natural or semi-natural vegetation are left intact. In the short term, such refuges need not be very large: Dickinson (1975) and Johnson (1977) recorded $M$. minutus on narrow roadside verges in, respectively, Milton Keynes and Lincoln, while the smallest habitat patch containing animals in the present study was 0.3 ha. However, the longer term persistence of $M$. minutus in urban areas may depend on additional factors such as the number and dispersion of suitable habitat patches, their proximity to source areas, and the degree of disturbance to which the patches are subjected. Dickman \& Doncaster (1986) suggest that small mammals generally do not perceive the urban environment, but they may be affected by it indirectly if urban processes modify the growth or structure of patch vegetation.

The omnivorous diet of $M$. minutus may be a factor allowing it to exploit the urban environment. For example, seed is the major dietary component in long grass and scrub, but fruit predominates in orchards due to the local abundance of apples and blackberries. Consumption 
28. Warner L. J. \& Batt G. T., 1976: Some simple methods for recording wild harvest mouse (Micromys minutus) distribution and activity. J. Zool., Lond., 179: $226-229$.

Accepted, March 3, 1986.

C. R. DICKMAN

UŻYTKOWANIE SRODOWISKA I DIETA BADYLARKI, MICROMYS MINUTUS, W WARUNKACH MIEJSKICH

\section{Streszczenie}

Bałano występowanie badylarki, Micromys minutus (Pallas, 1771), na 50 różnych powierzchniach w mieście Oxford, używając tub kontrolnych, umieszczonych w krzewach i roślinności zielnej (określanie gatunku po pozostawionej sierści) i pułapek żywołownych, oraz szukając gniazd. Badylarkę stwierdzono na 10 powierzchniach (o wielkości od 0.30 do $1.76 \mathrm{ha}$ ). Byly to najezęściej tereny gęsto porośnięte roślinnością (sady, zakrzaczenia i wysokie trawy), ale w pojedyńczych przypadkach wykryto obecność zwierząt $\mathrm{w}$ lesie, na terenie przykościelnym i w zarośniętym ogrodzie (Tabela 1). Analiza odchodów zbieranych w gniazdach i uzyskanych od złowionych osobników wykazała, że M. minutus jest zwierzęciem wszystkożernym. Nasiona, owoce, liście roślin jedno- i dwuliściennych oraz owady były najważniejszymi elementami diety. W małych ilościach zjadane były także inne bezkręgowce, grzyby, mech i korzonki (Tabela 2). 